\title{
Drug Repurposing in Oncology
}

\author{
Luxitaa Goenka ${ }^{1}$ Prasanth Ganesan ${ }^{1, \odot}$ \\ ${ }^{1}$ Department of Medical Oncology, JIPMER, Puducherry, India
}

Ind J Med Paediatr Oncol 2021;42:194-198.

\section{Introduction}

Several novel systemic cancer therapies have evolved in the last two decades. Oncology drug development has moved from "cytotoxic" agents to "targeted" drugs. More recently, immune modulation by drugs or cellular therapies has been added to anti-cancer armamentarium. ${ }^{1}$ Advances in basic cancer biology have aided these developments. However, we are far from achieving "cure" or "control" of most advanced cancers. There is a constant need to innovate and develop therapies to "outwit" the ever-mutating cancer cell. Canonical drug development models are painstakingly slow and very expensive and hence there is need to look for alternative options. It is in this space that drug repurposing fits whereby an existing drug (used for other nononcological indications) is used for treating tumors by virtue of its action on some of the "targets" presented by cancer. The increased understanding of the hallmarks of cancer and the development of various data-driven approaches have facilitated the science of drug repurposing in oncology. ${ }^{2}$

\section{Traditional Drug Development Models}

Potential compounds (with known or presumed anti-cancer properties) are identified (from nature/ microbes) and first evaluated in preclinical cellular/tissue culture models. These are then tested in animal models to understand the kinetics and dynamics and anticancer properties. Once the preclinical studies are successful, the drug must be formulated for human use and undergoes phase I testing for dose finding. This is followed by larger phase II and phase III clinical trials. Similar sequence of development is used for "targeted" drugs and immunotherapy drugs. However, this model requires 10 to 15 years from identification of a compound to final approval. It also requires considerable investment of resources, ultimately reflected in the exorbitant cost of newer molecules. ${ }^{3}$ Many potential agents, which look promising in the laboratory or even in animal models, fail in the clinic.

DOI https://doi.org/ $10.1055 / \mathrm{s}-0041-1733825$ ISSN 0971-5851
Address for correspondence Prasanth Ganesan, MD, DM, Department of Medical Oncology, JIPMER, Dhanvantri Nagar, Puducherry 605006, India (e-mail: p.ganesan@jipmer.edu.in).

\section{The Drug Repurposing Model: Advantages Over the Traditional Models}

"Drug repositioning" or "drug repurposing" is a model in which new targets and/or disease indications are identified for medicines that have already been approved (for other indications than cancer; - Fig. 1). These drugs have well-established pharmacological and safety profiles. ${ }^{4}$ Thus, we can proceed directly to testing the efficacy. Money and time are saved by skipping/shortening "dose-finding" and "toxicity-finding" studies. Since it is a marketed product, the drug is often 'out-of-patent' and multiple generics are available. Thus, the molecule would be inexpensive. For the reasons mentioned above, considerable interest has been kindled in repurposing agents to treat cancer. ${ }^{5}$ Collaborations such as "repurposing drugs in oncology" project have been initiated by several researchers seeking to repurpose well-known noncancer drugs for use in oncology. ${ }^{6}$

It has been estimated that repurposing can reduce the time duration for drug development from a 13 to 17 years to 3 to 7 years or lesser. ${ }^{7}$ The repositioned drugs are already approved, and their safety, toxicology, and bioavailability profiles are well known. These can enter clinical trial stages much faster, giving it accelerated developmental advantage over a nonrepositioned drug. The relaunch of a repositioned drug versus a new drug saves millions of dollars for a company. ${ }^{4}$

\section{Effects of Repurposed Agents in Cancer: The "On-Target" and the "Off-Target" Models}

The target of a repurposed agent can be a gene, a protein, an enzyme, or a chemical in the body/ tumor. ${ }^{8}$ In the "on-target" approach, the repurposed agent's use is based on its stated mechanism of action. A classic example would be aspirin, whose primary mechanism is cyclooxygenase-2 (COX-2) inhibition. When aspirin is used in oncology, we are still trying to exploit its effect on COX-2 that results in anticancer
(C) 2021 . Indian Society of Medical and Paediatric Oncology.
This is an open access article published by Thieme under the terms of the Creative
Commons Attribution-NonDerivative-NonCommercial-License, permitting copying
and reproduction so long as the original work is given appropriate credit. Contents
may not be used for commercial purposes, or adapted, remixed, transformed or
built upon. (https://creativecommons.org/licenses/by-nc-nd/4.0/).
Thieme Medical and Scientific Publishers Private Ltd. A-12, Second
Floor, Sector -2, NOIDA -201301, India 
effects. In the "off-target" approach, the "other" effects of a molecule that occur in addition to its primary action are exploited for anticancer efficacy. For example, valproic acid, a common antiepileptic, has primary action on voltage-gated ion channels in the nervous system. However, it has "other" actions such as inhibition of the histone deacetylases that has prompted studies of repurposing this agent in multiple cancers. ${ }^{9}$ In some cases, the "off-target" effect may be realized from the side effects caused by the drug ( $\mathbf{- T a b l e ~} \mathbf{1}$ ). A few examples of drugs that were successfully repurposed are detailed below.

\section{Selected Examples of Successful Repurposing in Oncology}

\section{Thalidomide in Multiple Myeloma: (“Off-target")}

Thalidomide was initially developed as an agent against morning sickness in pregnant women in the 1960s and 1970s. ${ }^{10}$ After initial notoriety due to teratogenic effects, the molecule was shelved for over two decades until it was successfully repurposed in the 1990s as an essential agent against multiple myeloma based on its antiangiogenic and immune-modulatory properties. ${ }^{11,12}$

\section{Olanzapine for the Prevention of Chemotherapy-Induced Nausea and Vomiting (CINV): ("On-target")}

Olanzapine was developed as an atypical antipsychotic. However, recognition of its effects on multiple dopaminergic pathways in the nervous system, which are also involved in emesis pathways, prompted clinical trials to treat and prevent chemotherapy-induced nausea and vomiting (CINV). ${ }^{13}$ Currently, it is considered a standard agent when using highly emetogenic chemotherapy. ${ }^{14}$

\section{Celecoxib in Oral Metronomic Therapy of Cancer ("on-target")}

Celecoxib is a selective inhibitor of COX-2 and was initially developed as a nonsteroidal anti-inflammatory agent. ${ }^{15}$ Recent studies from India have successfully demonstrated its use in phase III studies as a component of oral metronomic therapies for advanced cancer. ${ }^{16,17}$

\section{Approaches in Drug Repurposing}

Various computational approaches can be used to analyze large-scale data to generate hypotheses for repurposing opportunities. These strategies have been summarized in - Fig. 1 and have been reviewed extensively elsewhere. ${ }^{3}$ Drugs being studied for repurposing often have extensive human usage experience. These retrospective databases help us to understand the type of cancer and target population where these agents might be helpful. For example, data regarding reduced relapses of colorectal cancers among patients taking aspirin for cardiovascular conditions prompted the repurposing of this agent in prevention of cancers. ${ }^{4}$ Similarly, molecular docking studies using in silico approaches have been used to model the structural
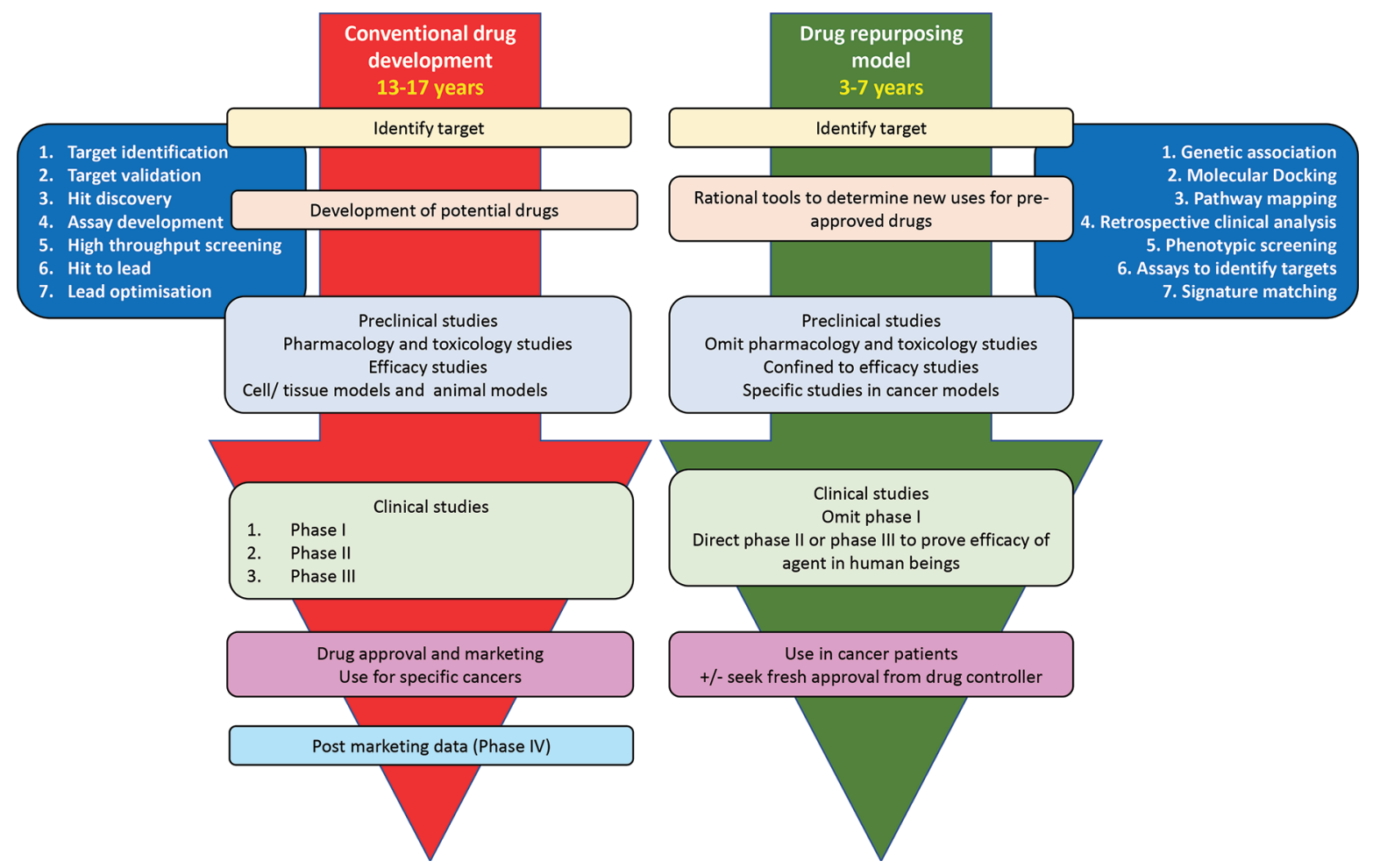

Fig. 1 Flow diagram showing the process of drug development comparing the traditional model with the repurposing-based approach. Since the repurposed drugs have preliminary data on human usage, basic pharmacology and toxicology studies in animal models can be often omitted. Similarly, dose-finding studies (phase 1) in humans can be omitted or fast-tracked with fewer dose levels. if found efficacious, physicians can use these molecules directly in the clinic without cumbersome regulatory processes 
Table 1 Drug repurposing in oncology-“On-target" and "Off-target" agents

\begin{tabular}{|c|c|c|c|c|c|}
\hline Drug & Mechanism & Primary use & "Target" in oncology & $\begin{array}{l}\text { Cancer types } \\
\text { studied }\end{array}$ & Status \\
\hline \multicolumn{6}{|l|}{ “On-target" agents } \\
\hline Aspirin ${ }^{21}$ & $\begin{array}{l}\text { COX-2 } \\
\text { inhibition }\end{array}$ & $\begin{array}{l}\text { Analgesic, } \\
\text { antiplatelet }\end{array}$ & COX-2 & $\begin{array}{l}\text { Colon, esophagus } \\
\text { ovary }\end{array}$ & $\begin{array}{l}\text { Strong evidence } \\
\text { for primary } \\
\text { and secondary } \\
\text { prevention } \\
\text { in colorectal } \\
\text { cancers }\end{array}$ \\
\hline Statins ${ }^{22}$ & $\begin{array}{l}\text { HMG Co-A } \\
\text { reductase }\end{array}$ & Lipid-lowering & $\begin{array}{l}\text { HMG Co-A reductase } \rightarrow \\
\text { mevalonate pathway }\end{array}$ & Ovary, colon, breast & In trials \\
\hline Metformin 23 & Multiple & Type 2 diabetes & $\begin{array}{l}\text { AMPK pathway leading } \\
\text { to downregulation of } \\
\text { mTOR and depletion of } \\
\text { p70. Cell cycle inhibition } \\
\text { through COX-2 }\end{array}$ & $\begin{array}{l}\text { Ovary, prostate, } \\
\text { breast, colon }\end{array}$ & In trials \\
\hline Mebendazole ${ }^{24}$ & $\begin{array}{l}\text { Inhibit the } \\
\text { synthesis of } \\
\text { microtubules } \\
\text { via binding } \\
\text { to colchicine } \\
\text { binding site of } \\
\beta \text {-tubulin }\end{array}$ & Antihelminthic & $\begin{array}{l}\text { Colchicine-binding } \\
\text { domain of tubulin } \\
\rightarrow \text { inhibition of tubulin } \\
\text { polymerization. }\end{array}$ & $\begin{array}{l}\text { Medulloblastoma, gli- } \\
\text { oma, and astrocytoma }\end{array}$ & $\begin{array}{l}\text { Phase II trial } \\
\text { showed benefit } \\
\text { in gliomas }\end{array}$ \\
\hline Vitamin $D^{25}$ & $\begin{array}{l}\text { Regulation of } \\
\text { gene expres- } \\
\text { sion by direct } \\
\text { binding to VDR } \\
\text { genes }\end{array}$ & $\begin{array}{l}\text { Rickets and } \\
\text { osteomalacia }\end{array}$ & $\begin{array}{l}\text { Binding to VDR genes } \rightarrow \\
\text { activation of tumor } \\
\text { suppressor genes }\end{array}$ & $\begin{array}{l}\text { Breast, ovary, } \\
\text { lymphomas }\end{array}$ & In trials \\
\hline Propranolol $^{6}$ & $\begin{array}{l}\text { Inhibition of } \\
\beta \text {-adrenergic } \\
\text { receptor }\end{array}$ & Hypertension & $\begin{array}{l}\text { Inhibit oncogenic } \\
\text { changes by blocking the } \\
\beta \text {-receptors }\end{array}$ & Angiosarcomas & In trials \\
\hline Losartan $^{6}$ & $\begin{array}{l}\text { Blocks the } \\
\text { binding of } \\
\text { angiotensin II } \\
\text { to the angio- } \\
\text { tensin I (AT1) } \\
\text { receptor }\end{array}$ & Hypertension & $\begin{array}{l}\text { Inhibition of the TGF- } \beta \\
\text { pathway and reduce the } \\
\text { extracellular matrix that } \\
\text { hinders drug delivery } \\
\text { and efficacy }\end{array}$ & $\begin{array}{l}\text { Pancreatic, malignant } \\
\text { ascites, ovary }\end{array}$ & In trials \\
\hline \multicolumn{6}{|l|}{ “Off-target" agents } \\
\hline Itraconazole ${ }^{26}$ & $\begin{array}{l}\text { Inhibition } \\
\text { of fungal } \\
\text { cytochrome } \\
\text { P-450- } \\
\text { dependent } \\
\text { enzyme } \\
\text { lanosterol } \\
\text { 14- } \alpha \text {-demeth- } \\
\text { ylase }\end{array}$ & Antifungal & $\begin{array}{l}\text { Hedgehog signaling } \\
\text { pathway, angiogenesis, } \\
\text { and autophagy and } \\
\text { reversal of multidrug } \\
\text { resistance }\end{array}$ & Ovary, prostate, lung & In trials \\
\hline Niclosamide $^{27}$ & $\begin{array}{l}\text { Inhibit } \\
\text { synthesis of } \\
\text { microtubules } \\
\text { via binding } \\
\text { to colchicine } \\
\text { binding site of } \\
\beta \text {-tubulin }\end{array}$ & Antihelminthic & $\begin{array}{l}\text { Inactivation of MEK } 1 / 2- \\
\text { ERK } 1 / 2 \text { mediated signal } \\
\text { transduction } \rightarrow \text { increased } \\
\text { apoptosis }\end{array}$ & $\begin{array}{l}\text { Colorectal cancer and } \\
\text { prostate cancer }\end{array}$ & In trials \\
\hline $\begin{array}{l}\text { Chloroquine } \\
\text { hydroxychloroquine }{ }^{28}\end{array}$ & $\begin{array}{l}\text { Inhibition of } \\
\text { antigen pres- } \\
\text { entation of the } \\
\text { cell, reducing } \\
\text { the inflamma- } \\
\text { tory response }\end{array}$ & $\begin{array}{l}\text { Antimalarial } \\
\text { connective tis- } \\
\text { sue disorders }\end{array}$ & Autophagy inhibition & $\begin{array}{l}\text { Ovary, pancreas, } \\
\text { breast, lung, } \\
\text { chondrosarcoma }\end{array}$ & In trials \\
\hline
\end{tabular}


Table 1 (continued)

\begin{tabular}{|l|l|l|l|l|l|}
\hline Drug & Mechanism & Primary use & “Target” in oncology & $\begin{array}{l}\text { Cancer types } \\
\text { studied }\end{array}$ & Status \\
\hline Ivermectin $^{29}$ & $\begin{array}{l}\text { The influx of } \\
\text { Cl- ions }\end{array}$ & Anthelmintic & $\begin{array}{l}\text { EGFR/ERK/Akt/NF-KB } \\
\text { pathway } \rightarrow \text { downregu- } \\
\text { lating the expression of } \\
\text { P-gp }\end{array}$ & $\begin{array}{l}\text { TNBC, CRC, lung, and } \\
\text { ovarian cancers }\end{array}$ & In trials \\
\hline Target unknown & Unknown & $\begin{array}{l}\text { Antiemetic, } \\
\text { sedative }\end{array}$ & $\begin{array}{l}\text { Possible antian- } \\
\text { giogenic effects, } \\
\text { immunomodulation }\end{array}$ & Multiple myeloma & Approved \\
\hline Thalidomide ${ }^{30}$ & \begin{tabular}{l}
$\mid l$ \\
\hline
\end{tabular}
\end{tabular}

Abbreviations: TGF- $\beta$, transforming growth factor beta; AMPK, adenosine monophosphate-activated protein kinase; COX-2, cyclooxygenase-2; CRC, colorectal cancer; EGFR, epidermal growth factor receptor; ERK, extracellular-regulated kinase; HMG Co-A, 3-hydroxy-3-methylglutaryl coenzyme A; mTOR, mammalian target of rapamycin; NF-kB, nuclear factor kappa B; TNBC, triple negative breast cancer; VDR, vitamin D receptor.

association between a potential cancer target and a candidate drug molecule. ${ }^{3}$

In the clinical testing phase, time-consuming phase I studies can be avoided as data are available regarding these drugs' maximum tolerated doses, toxicity, and kinetics. The required dosing as an anticancer agent can be assumed from this previous data. However, small phase I studies may still be conducted with repurposed agents to identify the correct dose, especially when the agent is planned to be used in combination with other drugs.

Indian regulatory guidelines specify that "new indication for old drug" studies must get approval from Central Drugs Standard Control Organization (CDSCO). However, as per the new drug and clinical trial rules (2019) "non-regulatory" studies need not obtain specific approval from CDSCO. ${ }^{18}$ Investigator-initiated "academic" studies with repurposed drugs can be approved by the local institutional ethics committee. This is the right step that significantly eases the conduct of studies with repurposed agents.

\section{Applying the Data from Repurposing Studies to Practice}

Once a repurposed agent is found to be useful in phase III studies, it may be directly used by clinicians as an "off-label" indication in oncology. One example is the widespread use of olanzapine for CINV. There is extensive data, but no "regulatory" approval of olanzapine to prevent CINV.

However, if a pharmaceutical company desires to obtain regulatory approval for the new indication, it may need to conduct additional studies with the label of a "regulatory" trial. The more stringent rules of pharmaceutical-sponsored trials would apply. There may be a need to establish a dose-response relationship for the new indication..$^{19}$ The license for a further indication might depend not only on the regulatory evidence such as quality, efficacy, and safety but also on assessment comparing the clinical efficacy versus cost-effectiveness. ${ }^{20}$

\section{Drug Repurposing: Caveats}

Repurposed drugs are rarely effective as monotherapies. Combination studies must be appropriately designed to identify the correct dose and scheduling of agents. ${ }^{5}$ Thus, phase I studies cannot be always eliminated. The anticancer doses may be higher than that which is used in usual practice for other indications resulting in unexpected toxicities. Funding is still required to conduct these types of studies and must be sought through various agencies by the investigator. The pharmaceutical industry may not be keen to invest in these studies. ${ }^{3}$

\section{Conclusion}

The development of new anticancer drugs is expensive and has a low success rate. The drug repurposing approach offers advantages of faster development, lesser cost, and broader application. Though many studies with repurposed agents in cancer are going on, the number of drugs that have found clinical application are few (-Table 1). Newer approaches using genetic association and molecular docking may help to speed up the process of repurposing.

\section{Conflicts of Interest}

None of the authors have any relevant conflicts of interests to declare.

\section{Acknowledgments}

None.

\section{References}

1 Falzone L, Salomone S, Libra M. Evolution of cancer pharmacological treatments at the turn of the third millennium. Front Pharmacol 2018;9:1300

2 Blackadar CB. Historical review of the causes of cancer. World J Clin Oncol 2016;7(1):54-86

3 Pushpakom S, Iorio F, Eyers PA, et al. Drug repurposing: progress, challenges and recommendations. Nat Rev Drug Discov 2019;18(1):41-58

4 Zhang Z, Zhou L, Xie N, et al. Overcoming cancer therapeutic bottleneck by drug repurposing. Signal Transduct Target Ther 2020;5(1):113

5 Sleire L, Førde HE, Netland IA, Leiss L, Skeie BS, Enger PØ. Drug repurposing in cancer. Pharmacol Res 2017;124:74-91

6 Pantziarka P, Bouche G, Meheus L, Sukhatme V, Sukhatme VP, Vikas P. The repurposing drugs in oncology (ReDO) project. Ecancermedicalscience 2014;8:442 
7 Juárez-López D, Schcolnik-Cabrera A. Drug repurposing: considerations to surpass while re-directing old compounds for new treatments. Arch Med Res 2021;52(3):243-251

8 Jourdan J-P, Bureau R, Rochais C, Dallemagne P. Drug repositioning: a briefoverview.JPharmPharmacol2020;72(9):1145-1151

9 Soria-Castro R, Schcolnik-Cabrera A, Rodríguez-López G, et al. Exploring the drug repurposing versatility of valproic acid as a multifunctional regulator of innate and adaptive immune cells. J Immunol Res 2019;2019:9678098

10 Vargesson $\mathrm{N}$. Thalidomide-induced teratogenesis: history and mechanisms. Birth Defects Res C Embryo Today 2015;105(2):140-156

11 Rehman W, Arfons LM, Lazarus HM. The rise, fall and subsequent triumph of thalidomide: lessons learned in drug development. Ther Adv Hematol 2011;2(5):291-308

12 Singhal S, Mehta J, Desikan R, et al. Antitumor activity of thalidomide in refractory multiple myeloma. $\mathrm{N}$ Engl J Med 1999;341(21):1565-1571

13 Fonte C, Fatigoni S, Roila F. A review of olanzapine as an antiemetic in chemotherapy-induced nausea and vomiting and in palliative care patients. Crit Rev Oncol Hematol 2015;95(2):214-221

14 Hesketh PJ, Kris MG, Basch E, et al. Antiemetics: American Society of Clinical Oncology Clinical Practice Guideline Update. J Clin Oncol 2017;35(28):3240-3261

15 Zarghi A, Arfaei S. Selective COX-2 inhibitors: a review of their structure-activity relationships. Iran J Pharm Res 2011;10(4):655-683

16 Patil V, Noronha V, Dhumal SB, et al. Low-cost oral metronomic chemotherapy versus intravenous cisplatin in patients with recurrent, metastatic, inoperable head and neck carcinoma: an open-label, parallel-group, non-inferiority, randomised, phase 3 trial. Lancet Glob Health 2020;8(9):e1213-e1222

17 Palve V, Liao Y, Remsing Rix LL, Rix U. Turning liabilities into opportunities: off-target based drug repurposing in cancer. Semin Cancer Biol 2021;68:209-229

18 NewDrugs_CTRules_2019. New Drugs and Clinical Trials Rules 2019. [home page on Internet]. C2021 [updated 2019 Mar 19; cited 2021 Apr 06]. Available from: https://cdsco.gov.
in/opencms/export/sites/CDSCO_WEB/Pdf-documents/ NewDrugs_CTRules_2019.pdf. Accessed July 12, 2021

19 Hernandez JJ, Pryszlak M, Smith L, et al. Giving drugs a second chance: overcoming regulatory and financial hurdles in repurposing approved drugs as cancer therapeutics. Front Oncol 2017;7:273

20 Breckenridge A, Jacob R. Overcoming the legal and regulatory barriers to drug repurposing. Nat Rev Drug Discov 2019;18(1):1-2

21 Zhang Z, Chen F, Shang L. Advances in antitumor effects of NSAIDs. Cancer Manag Res 2018;10:4631-4640

22 Joharatnam-Hogan N, Alexandre L, Yarmolinsky J, et al. Statins as potential chemoprevention or therapeutic agents in cancer: a model for evaluating repurposed drugs. Curr Oncol Rep 2021;23(3):29

$23 \mathrm{Yu} \mathrm{H}$, Zhong X, Gao P, et al. The potential effect of metformin on cancer: an umbrella review. Front Endocrinol (Lausanne) 2019;10:617

24 Guerini AE, Triggiani L, Maddalo M, et al. Mebendazole as a candidate for drug repurposing in oncology: an extensive review of current literature. Cancers (Basel 2019;11(9):E1284

25 Sheeley MP, Andolino C, Kiesel VA, Teegarden D. Vitamin D regulation of energy metabolism in cancer. Br J Pharmacol 2021. doi: $10.1111 /$ bph.15424

26 Pounds R, Leonard S, Dawson C, Kehoe S. Repurposing itraconazole for the treatment of cancer. Oncol Lett 2017;14(3):2587-2597

27 Wang L-H, Xu M, Fu L-Q, Chen X-Y, Yang F. The antihelminthic niclosamide inhibits cancer stemness, extracellular matrix remodeling, and metastasis through dysregulation of the nuclear $\beta$-catenin/c-Myc axis in OSCC. Sci Rep 2018;8(1):12776

$28 \mathrm{Xu} \mathrm{R}, \mathrm{Ji}$ Z, Xu C, Zhu J. The clinical value of using chloroquine or hydroxychloroquine as autophagy inhibitors in the treatment of cancers: a systematic review and meta-analysis. Medicine (Baltimore 2018;97(46):e12912

29 Tang M, Hu X, Wang Y, et al. Ivermectin, a potential anticancer drug derived from an antiparasitic drug. Pharmacol Res 2021;163:105207

30 Singhal S, Mehta J. Thalidomide in cancer: potential uses and limitations. BioDrugs 2001;15(3):163-172 